\title{
Chapter 8 \\ The (De-)Contextualization of Geographical Knowledge in Forest Fire Risk Management in Chile as a Challenge for Governance
}

\author{
Michael Handke
}

With their annual reports, large and integrated forestry companies and insurance companies in Chile signal specific knowledge and a sophisticated language on the value of risk to the financial markets (Kalthoff, 2005). In the course of this, they have developed their own way of risk communication, which decouples risk from its geographical context. This is remarkable in that forestry activities are initially deeply rooted into physical space and socially embedded in regional communities.

In January 2017, Chile experienced the worst forestry calamity in recent history. More than 120 simultaneous wildfires in the O'Higgins, Maule, and Biobio regions affected nearly 467,000 hectares of native forest and tree plantations (CONAF, 2017). While the real ecological and economic damage caused by the fires was significant and had far-reaching social consequences for many people, the associated financial losses on the timber markets proved to be manageable. Economic players spread it among themselves on several shoulders. Empresas CMPC S.A., for example, a multinational holding company of Chilean origin, a paper manufacturer, and also the country's second largest forestry company, announced that the plantation property affected by the fires reached approximately 19,000 hectares, equivalent to US\$73 million of economic damage. However, CMPC also assured that the timber supply for plant operations remained unaffected and that the financial stability of the company was not at risk (CMPC, 2018). In retrospect, insurance companies with whom CMPC had signed insurance policies compensated up to US\$17 million of the damage. The Chilean insurance sector reported similar outcomes. HDI Seguros S. A., for example, the fourth-largest insurance company in Chile and an innovator in forest fire insurance policies, recorded losses due to the catastrophe amounting to US\$20.2 million, of which 17.2 million (or 85\%) were still covered by reinsurance contracts (HDI, 2018). Statements like these make clear that from an economic point of view it is possible to decouple the physical dimension of the risk

M. Handke (ه)

Department of Geography, Heidelberg University, Heidelberg, Germany

e-mail: handke@uni-heidelberg.de 
(i.e., the occurrence of forest fire events in space) from its economic (i.e., the losses of forested areas) and financial dimension (i.e., profit warnings).

The risk management of the Chilean forest companies combines hierarchical orders with abstract market mechanisms: On the one hand, forestry companies reduce the probability of wildfire occurrence and the magnitude of losses with modern standards of tree-plantation management that include, among other things, the maintenance of watchtowers and the employment of fire brigades. With their sophisticated forest logistics, they are able to extract timber resources even from burnt trees. Hierarchical orders are executed in space trough corporate routines (see also Perrow, 1986, 1972; or Becker \& Knudsen, 2005). On the other hand, they apply a market solution of risk management as they purchase insurance policies and other services from the financial markets that allow them to individual hedge the risk of economic losses (Chichilnisky \& Heal, 1998). Insurance transforms risk into a commercial good. The insured pays an insurance premium to compensate the insurer for assuming the risk. In other words: The insured gives up part of his profits and turns incalculable uncertainties into calculable stability (Dean, Doyle, \& Ericson, 2003; Freeman \& Kunreuther, 1997). Insurance markets as an instrument of risk management to reduce the economic vulnerability of social actors have gained importance in Chile in recent years (Cifuentes, Desormeaux, \& González, 2002; Loewe, Corti, Ruiz, \& Lobo, 2017). ${ }^{1}$

The strategies and practices of dealing with forest fire risks in Chile are a proper object of conceptual and empirical research (Úbeda \& Sarricolea, 2016) — especially from an economic geographical perspective. When aggregated figures that primarily contain economic indicators express the magnitudes of risks decoupled from their geographical context, it is no longer easy to understand how wildfires occurred in first place and what additional socio-economic consequences they might have for the people living in forestry regions. Quantification is useful for the economic control of risks, but it restricts knowledge about risk (Beck, 1992; Luhmann, 1991/1993; Viscusi \& Magat, 1987). A society that relies mainly on economic risk management practices consequently loses its ability to respond appropriately to changing causes and consequences of risk (Rosa, Renn, \& McCright, 2014).

The devastating forest fires in Chile in early 2017 have certainly increased the society's overall sensitivity to this kind of risk scenario. They uncovered the vulnerability of various stakeholders in society and their powerlessness in making real decisions about risks. While the risk management of forestry and insurance companies mainly takes place behind closed doors, whereby annual balance sheets signal that forest fires are economically controllable, other affected stakeholders are struggling to deal with the consequences. This not only raises the question of how a society should deal with risk in appropriate ways; simultaneously, there is a growing interest in opening the black box of the companies' internal risk management systems to screen them for unintended negative external effects (Bottaro, Roco, Pettenella, Micheletti, \& Vanhulst, 2018; van Dam, 2006).

\footnotetext{
${ }^{1}$ As Chile is frequently hit by natural disasters, the country's insurance industry is required by law to make use of reinsurance. This regulation aims at both stimulating the national insurance market and making it more predictable and financially stable.
} 
The extent to which markets and hierarchical types of risk management (and the corresponding risk knowledge) are suitable for improving forest fire risk prevention in the Chilean society as a whole or, generally speaking, for increasing society's resilience to risk, which is the concern of the broader concept of risk governance, remains an open question that motivates the following analysis. How can actors utilize hierarchical and market approaches to risk management jointly in the process of risk governance?

Risk management and risk governance are not the same. The differences lie not only in the perspective of the involved actors (individual versus collective risk handling) or in the time horizon underlying the risk practices (short-term versus longterm orientation), but above all in the production and usage of sophisticated risk knowledge: Risks arise in knowledge, and therefore in knowledge they can be reduced, enlarged or simply eliminated from consciousness (Beck, 1992). A perspective of risk knowledge, therefore, not only promises to clarify the differences between management and governance but also the interrelations between different risk management practices.

By revealing the strengths and weaknesses in the interaction between hierarchical and market forms of forest fire risk management in Chile and focusing on the epistemological challenges related to the geographical (de-)contextualization of risks, in this paper I contribute to a better understanding of the societal benefits and challenges of explicitly regional risk governance approaches. Those approaches, however, have yet to be put in practice in Chile.

I proceed in four parts. Following this introduction, I use the first section to explain and justify the relevance of the research problem concerning the challenges of different knowledge perspectives in dealing with risks. I make an explicit distinction between risk management and a risk governance perspective. In the second section, I analyze the different characteristics of forest fires in Chile. Applying the risk governance approach of Rosa et al. (2014, see also Chap. 5 by Renn), I argue that the relationships between wildfires' causes and effects are epistemologically complex, ambiguous, and uncertain. I make it clear that a deliberate spatiotemporal view is needed to understand these relationships and to be able to react to evolving risk situations. In the third section, I then contrast these findings with an analysis of the management practice of forestry and insurance companies in dealing with wildfire risks in Chile. Drawing on semi-structured interviews with forest owners and executives of insurance companies conducted between 2014 and 2019, I examine how hierarchical and market-based forms of risk management complement each other and, in parallel, limit the use of risk knowledge. It becomes clear that where specific knowledge is lacking or too expensive to produce, actors adopt risk avoidance strategies rather than investing in collective learning processes. In the fourth section I interpret these risk management practices as a decontextualization of risk and risk knowledge that stands in the way of a more collective and regional approach of forest fire risk governance. The paper concludes with a call for a broader and explicitly geographical perspective of wildfire risk governance in Chile. 


\section{The Challenges of Governing Economic Uncertainties}

Researchers use the notion of risk to describe the contrast between reality and possibility (Hacking, 1990) and refer to a future that is visible only through the eyes of the present. People who take risks know that their decisions are accompanied by several possible consequences, but only when the risk actually turns into losses are they aware of its true characteristics and consequences. In the meantime, actors use discursive risk knowledge to shape (and strategically manipulate) the ideas and perceptions of risk that circulate in society (González-Hidalgo \& Zografos, 2017; Martin, Martin, \& Kent, 2009). Risks are real phenomena that are simultaneously socially constructed and discursively amplified. Actors must therefore grasp, assess, and manage the use of sophisticated and interdisciplinary knowledge (Rosa et al., 2014), which also places high demands on knowledge for governance (Glückler, Rehner, \& Handke, 2019).

From an economic point of view, the future's unpredictability is nothing to be intimidated by. Risks are part of entrepreneurial ventures and promise aboveaverage returns. Whoever succeeds in controlling risks better than others will be prosperous in the market (Clark, 2018; Knight, 1921). With this line of argument, it is easy to ignore that individual decisions about risk in the economy most often coincide with external effects for other social stakeholder. Forest fire risks are no exception. Certain tree-plantation management practices, for example, which are associated with varying degrees of accident probability, can trigger forest fire events, which, under certain climatic conditions, can quickly spread from their location of origin to neighboring areas and even endanger human settlements as they burn through the landscape (Bottaro et al., 2018). Many may suffer losses, even if they did not originally take any decisions on risk. While risk managers can easily justify economic losses due to risk in retrospect—by simply referring to the limited knowledge of risk that was available at the time of the decision and assure the best possible precautionary handling of it (Luhmann, 1991/1993)—other social stakeholders have greater difficulties in explaining and enforcing their positions. Social responsibilities in risk taking often remain unclarified.

Incomplete knowledge about risks, unintended side effects, and other "unknown unknowns" (Beck, 2006, p. 335), which can be summarized under the term systemic risk, are fundamental challenges for risk governance (Rosa et al., 2014). Ultimately, the way knowledge of risk is communicated determines the success or failure of management and governance practices. Yet, what exactly are the differences between them?

In general, risk management aims at objectively defining probable outcomes of decision making in order to reduce uncertainty to a list of probable events (following Beckert, 2016). More specifically, organizational risk management guides and legitimizes decision-making processes at the management level of a corporation and helps coordinating the available resources in pursuit of strategic objectives (Lundqvist, 2015; Soin \& Collier, 2013). Risk from the point of view of an enter-

prise is technically regarded as a cost factor, where the probabilities of harmful events' occurrences are offset against the value of expected losses (Knight, 1921). 
Risk managers calculate risks by making use of historic and quantifiable data. Nowadays, sophisticated risk models allow risk management to be based on individual decisions made by experts who aim at maximizing profit or-to put it differently-reducing the company's vulnerability. Risk management is short- to medium-term in nature depending on the forecasting capability of the available risk models.

The perspective of risk governance broadens the scope of the actors involved in risk management and their relations towards each other. From a societal perspective, governance in general terms serves to coordinate the collective actions of legally independent stakeholders toward the achievement of consensual goals. It extends beyond the scope of a single authority and requires negotiation between vested interests (Glückler et al., 2019). Risk governance, in particular, covers processes that lead to collectively binding decisions and the establishment of legitimized risk-management standards and practices that help to regulate, reduce, or control collective problems of risk (Crouch \& Keune, 2012; Renn, 2008; van Asselt $\&$ Renn, 2011). In this sense, researchers of risk governance analyze the institutional structures, power constellations between various stakeholders, and political processes in society. Governance is a collective learning process with a long-term time horizon. It focuses on context-specific collective solutions aimed at increasing the resilience of societal stakeholders (Young, 2010).

The challenges of risk governance are clearly associated with the complexity, ambiguity, and/or uncertainty of knowledge about risk (Rosa et al., 2014). Only rarely can actors comprehensively describe and calculate risk via linear correlations. Complexity, ambiguity, and uncertainty are attributes of risks that-if empirically distinguishable-imply different governance mechanisms. Therefore, risk governance uncovers and negotiates dissimilar risk interpretations and creates new knowledge to deal with inconclusive and unknown risk correlations.

How can risk management and risk governance practices beneficially complement each other in the context of forest fire risk? Perhaps they stand in each other's way because of their incommensurable handling of knowledge about risk? In the following I draw attention to these unanswered questions and apply them to the empirical case of Chile's risk-laden forestry sector.

\section{Methodology}

In order to address the aforementioned questions, I process the findings from several empirical studies on risk in the Chilean forestry and timber industry. These studies were conducted between 2014 and 2018 as part of different seminar courses in the M.Sc. Governance of Risk and Resources Master's program at the Heidelberg Center for Latin America. The courses contrasted theoretical insights into risk governance with the practical efforts of economic actors in dealing with real risk phenomena. From the outset, the empirical investigations aimed at recording the context-related risk perceptions of different actors exposed to wildfires and 
analyzing their influence on joint efforts in dealing with them regionally. Interestingly, the many surveyed actors rarely perceived forest fires in Chile as a collective risk. Individual efforts to minimize economic losses predominate.

Since wildfires cannot be assessed by deterministic or probabilistic hypotheses alone, a triangulation of different methods of qualitative social research proved to be appropriate for the collection of the empirical data (Flick, 2018): (i) First and foremost, I based this contribution on an extensive evaluation of scientific literature on forest fire risks in Chile. In this way, I was able on the one hand to shed light on the fundamental interdisciplinary complexity of the relationships between causes and effects in wildfires. On the other hand, I could get familiar with the way in which scientific knowledge on wildfires is reduced and generalized in contemporary risk models. (ii) I supplemented the literature review with a content analysis of discursive arguments on the causes and effects of forest fires, as they are discussed in Chilean trade journals such as Lignum, Revista Mundo Forestal, and Revista CIFOR, or in the general press. ${ }^{2}$ I included more than 250 newspaper articles and reports on forest fires in Chile that occurred between 2008 and 2018 in my analysis. This not only provided additional insights into the region-specific particularities of forest fire risks, but also confirmed the wide spread of strongly generalized explanations of the phenomenon of forest fires. Both indicate the discursive use of knowledge on risk (van Dijk, 2014). (iii) Thirdly, I have included an analysis the official Chilean forest fire statistics (CONAF, 2018) as well as an evaluation of the annual reports of the large Chilean forestry companies in the present study to highlight the regional diversity and temporal variability of risk. The statistics clearly reveal the quantitative extent of individual catastrophic wildfire events, which vary greatly from year to year and from region to region. They also differentiate between different affected parties (owners of natural forests versus owners of plantation forest of different size). (iv) Finally, I based this contribution on 25 expert interviews with risk managers from insurance companies in Santiago de Chile and economic actors at risk in the Chilean forest regions (primarily in the Maule and Biobio regions). I conducted the interviews as open, guideline-based interviews.

Precisely because different economic actors perceive forest fire risk differentlydepending on their contextual experiences-and evaluate and communicate it differently-depending on the use of risk-calculating methods-it is necessary to survey these risk experts and their interactions with each other as an additional object of investigation. Contextually differentiated risk knowledge influences the risk behavior of these actors in many ways (Müller-Mahn, Everts, \& Stephan, 2018). Ultimately, it determines the possibilities to develop a collective view on risk as the result of governance efforts.

\footnotetext{
${ }^{2}$ These include national newspapers such as www.elmercurio.com; www.latercera.com; www. elmostrador.cl; www.cnnchile.com, but also regional media such as www.diarioelcentro.cl; www. redmaule.com; www.diarioconcepcion.cl; www.biobiochile.cl. Only online articles from these newspapers were analyzed. Critical online news portals such as www.terram.cl; www.mapuexpress.org; www.laizquierdadiario.cl were also included in the research.
} 
Qualitative research does not end with a comparison of the collected data with the aim of explaining similarities between the units of research. Rather, it uncovers phenomena and associated variants for which case-specific explanations have to be developed (Crang, 2002). With my qualitative research approach, I was able to uncover contradictions and decode the relationship between realities and interpretations of risk (see also Eisenhardt, 1989). Contradictions in knowledge and practices are manifold when it comes to forest fire risks in Chile.

\section{Complexity, Ambiguity, Uncertainty? Forest Fire Risks in Chile}

Wildfires are typical for Mediterranean climate zones that are characterized by mild and rainy springs that are followed by dry summers. They are also a natural phenomenon in several regions in south-central Chile (McWethy et al., 2018). Wildfires are eminently spatial: They have an unmistakably definable place of origin from which they extend by geophysical laws to nearby spaces. However, nowadays they are mainly man-made phenomena. In many cases, they are caused by carelessness, accidents, or even arbitrary arson (O'Flanagan, 1997). In this sense, wildfires represent negative externalities of the expansion of human activities.

In Fig. 8.1, I provide an overview of the frequency of wildfire events in Chile since the 1990s. On average, almost 6,000 forest fires occur in the course of a year and around ten hectares of forested land are lost per event. Two thirds of the affected areas are natural landscapes such as natural forests, shrubs, and grasslands. However, plantation forests are also affected, and this trend is rising (Julio, 2014). Most recently, a drought phase that lasted several years led to the biggest forest fires in Chilean history (González, Gómez-González, Lara, Garreaud, \& Díaz-Hormazábal, 2018). The overall dimension of destructiveness of the latest "firestorm" (Gobierno de Chile, 2017) in terms of burned areas stands out in Fig. 8.1.

To some extent, researchers can assess the risk of wildfires with linear correlations that refer to physical-geographical conditions (Castillo, MolinaMartínez, Rodríguez y Silva, \& Julio, 2013). In the jargon of forestry authorities, who monitor the wildfire risk, one speaks for example of the rule of 30-30-30. The rule says that temperatures above $30{ }^{\circ} \mathrm{C}$, gusts of wind of the order of $30 \mathrm{~km} / \mathrm{h}$ or more, and a relative humidity of less than $30 \%$ raises the risk of wildfires significantly. It is undisputed that under extreme weather conditions wildfires are hard to control and can quickly expand into neighboring spaces. On the basis of these findings, authorities then may publish timely risk warnings to raise public awareness of the potential hazard. Topography has another direct effect on the speed at which forest fires spread. The steeper the slope, the greater the flames' inclination, which increases heat development on the ground and allows biomass to burn faster and more intensively. This knowledge is of practical importance in firefighting (Vélez, 2009). 


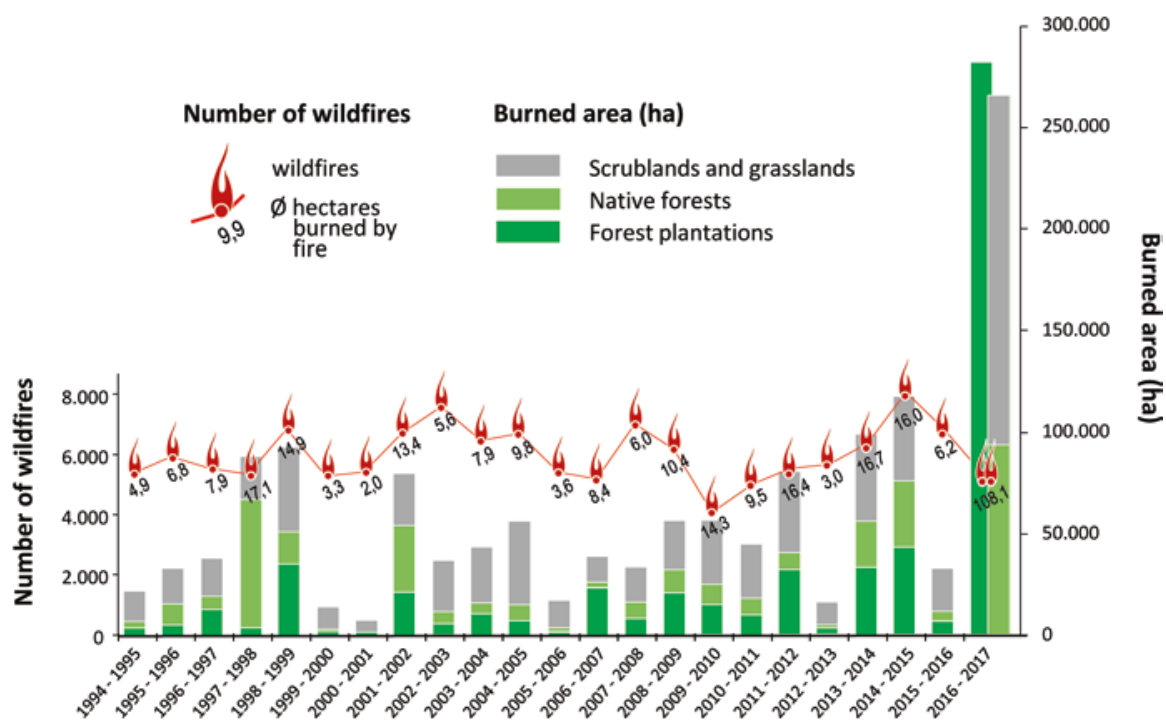

Fig. 8.1 The evolution of forest fire events and damage in Chile from 1994-2017. Source: Design by author. Data: Own calculations based on CONAF (2018)

However, natural factors alone cannot fully explain the extent of forest fires in Chile (Gómez-González et al., 2019). They may explain the size and spread of the flames and therefore the damage dimension of the risk. The occurrence and causes of fires, however, usually have an anthropogenic background. Risk analyses, for example, reveal the highest probabilities of forest fires occurring near settlements and along road networks (Martínez, Martínez, \& Martín, 2004). There, man is reckless in treating nature. Land use forms and the compositions of tree species in Chile's economically exploited forests plantations influence on the dimension of forest fire risk as well. This relationship, however, is anything but conclusively clarified (see, e.g., the controversial debate published in Mundo Forestal by GomézGonzález \& Espósito, 2017). To be able to capture the phenomena of forest fires in Chile, researchers must consider both physical geographical and anthropogenic contextual factors jointly. Interdisciplinary research is indispensable, which, however, leads to challenges of complexity, ambiguity, and uncertainty of knowledge about risk (Rosa et al., 2014).

It is very common in the risk management literature to describe risks as complex, ambiguous, and uncertain in order to differentiate them epistemologically (Brugnach \& Ingram, 2012; Cabantous, 2007; Ericson \& Doyle, 2004; Ilin \& Varga, 2015; Johansen \& Rausand, 2015; Knight, 1921; Müller-Mahn et al., 2018; Perrow, 1986, 1972). In short, the three characteristics of risk can be distinguished as follows (see also Rosa et al., 2014): Complexity characterizes a condition where it is difficult to identify and quantify exactly the potential causal relationships between aspects of risk and possible adverse effects of decision making on risk. Ambiguity corresponds to the phenomenon that various actors know risk differently, resulting in a 
variability of legitimate risk interpretations with respect to observations and evaluations of identical data. Uncertainty refers to unknown knowledge about certain causal relationships. That includes not knowing what one does not know.

One way of dealing with these challenges is through regulation. Standards and norms help actors reduce complexity, clarify ambiguities, and improve the reliability of mutual expectations (North, 1990). In Chile, for example, in 2015 the National Institute for Standardization published the norm NCh3380 that aimed at uniformly measuring wildfire risks (INN, 2015). The norm establishes a terminology and classification of risks of forest fires in plantations, for which it defines and delimits spatially different levels of risks, based on the evaluation of probabilities of occurrence and the different impacts caused by wildfires. The norm consolidates interdisciplinary knowledge and is considered " $[\ldots]$ applicable to any existing forest plantation in the country, regardless of the species it contains, size, location, among others" (INN, 2015, p. 2). This, however, raises a new challenge. Although the norm covers geographically correlated aspects of risk and makes them comparable, it misleads one to believe that the resulting risk models can be applied uniformly, that is independently of time and space. Such an approach in particular would mask and decontextualize the uncertain and ambiguous circumstances of the risk. Standardized models always entail the challenge of being able to capture evolving or systemic risks (MacKenzie, 2011). Well, what exactly leads to complexity, ambiguity and uncertainty in relation to forest fire risks in Chile and how to deal with it?

\section{Complexity: Multidirectional Correlations Between Physical and Anthropogenic Factors}

It is an obvious choice to start with the Chilean forestry sector with its specific ways of organizing economic activities in space (Clapp, 1995; Gatica, 2012) to illustrate how complex links between anthropogenic and natural factors of wildfire risks are created. Forestry companies, in first place, decide the composition of tree species in their forest plantations. They prefer exotic species such as eucalyptus or pine, as these are adapted to dry climatic conditions, grow rapidly, and are therefore economically very profitable. ${ }^{3}$ However, as both species have a higher water consumption than native trees, they can intensify droughts on a microgeographical scale and fuel the effects of fires (Little, Lara, McPhee, \& Urrutia, 2009). At the same time, however, industrial measures of plantation management significantly reduce the magnitude of forest fire risk. In their quest for higher yields, forestry companies remove "interfering biomass" from forest plantations and thus control an important fire accelerator. By investing in watchtowers that they strategically place within their territories, they create and maintain an interconnected monitoring system that

${ }^{3}$ Currently, pines account for $58 \%$ of all plantation area in Chile, while eucalyptus represent $36 \%$ (CONAF, 2018). 
allows for wildfires being detected in time (Tapia \& Castillo, 2014). The companies' own fire brigades can quickly reach out to a fire's source through laid forest paths. If the probability of the occurrence of fires remains constant, plantation management measures reduce the damage dimension of risk-although this relationship is not linear. Many risk-increasing and risk-reducing factors cannot be measured simultaneously in an accurate way. This is how complexity is created, and-by the way - a methodological problem for many forecasting risk models (Castillo et al., 2013). Normative assumptions on the weightings of individual factors must be chosen for these models to work.

Table 8.1 summarizes regional forestry activities in Chile and illustrates the complexity of the relationships between physical and anthropogenic factors of wildfire risks. In Chile, the probability of forest fire occurrence should actually decrease in the direction of the southern forest regions, as these are characterized by climatic conditions with lower average temperatures over the course of the year and generally record higher precipitation (Altamirano, Salas, Yaitul, Smith-Ramirez, \& Ávila, 2013). A glance at Table 8.1, however, reveals that forest fires in the south occur more frequently in absolute terms and measured in terms of available forest areas than in the northern forestry regions. It is also a fact that in the regions of Bio Bio and Araucanía, forest fires occur much more frequently in plantation forests than in natural forests. Simultaneously, however, plantation fires are significantly less destructive than fires that affect native forest.

The search for explanations of these findings leads to the question of who invests in firefighting in the first place and who decides which sources of fire are extinguished first when several fires occur simultaneously. Since firefighting in Chile is largely subject to a market in which private companies offer their services-and in which the economic value of the timber resources often determines the availability of fire brigades - it is understandable that wildfires in Chile provoke critical interpretations of the country's neoliberal forestry model (Barton \& Román, 2012; Reyes

Table 8.1 Forestry activities and forest fires in Chile

\begin{tabular}{|c|c|c|c|c|}
\hline & $\begin{array}{l}\text { O'Higgins } \\
\text { (VI) }\end{array}$ & $\begin{array}{l}\text { Maule } \\
\text { (VII) }\end{array}$ & $\begin{array}{l}\text { Bio Bio } \\
\text { (VIII) }\end{array}$ & $\begin{array}{l}\text { Araucania } \\
\text { (IX) }\end{array}$ \\
\hline Forested areas 2014 [hectares] & 586,615 & 833,227 & $1,695,082$ & $1,447,635$ \\
\hline Forest plantations 2014 [hectares] & 127,306 & 448,513 & 926,530 & 483,482 \\
\hline $\begin{array}{l}\text { Annual fire events (annual average } \\
\text { 2003-2016) [absolute number] }\end{array}$ & 222 & 437 & 2,499 & 1,006 \\
\hline Forest fires per 1000 hectares & 0.38 & 0.52 & 1.47 & 0.69 \\
\hline [\%] of events affecting plantations & 1.4 & 15.5 & 59.1 & 56.0 \\
\hline $\begin{array}{l}\text { Annual damage (all forests) (annual } \\
\text { average 2003-2016) [hectares] }\end{array}$ & 7,927 & 7,001 & 13,487 & 5,996 \\
\hline $\begin{array}{l}\text { Damage to native forests [hectares by } \\
\text { fire] }\end{array}$ & 35.1 & 17.7 & 11.1 & 9.3 \\
\hline Damage to plantations [hectares by fire] & 38.6 & 17.4 & 1.9 & 3.3 \\
\hline
\end{tabular}

Note. Personal elaboration with statistical data from CONAF (2018) 
\& Nelson, 2014). In relation to these interpretations, the ambiguous characteristics of risk come into play.

\title{
Ambiguity: The Coexistence of Several Equally Logical Explanations for Forest Fires in Chile
}

\begin{abstract}
"Risks only gain influence in the social world to the extent that they are communicated" (Renn, 2008, p. 57). Therefore, it is through discursive knowledge (van Dijk, 2014) that risks are socially constructed. Those who have experienced flames that directly affected their livelihoods describe and explain wildfire risks differently than those who only look at them from a distance. Geographical knowledge of complex risk relationships gives profound explanatory substance to these discourses. However, with geographically founded, context-dependent explanations actors can quickly confront the distanced with supposed ambiguity.
\end{abstract}

In Chile, many different discursive explanations circulate about the origins and the hazardous effectiveness of forest fires. They certainly feed on the heterogeneity of the society's risk knowledge. The ambiguity of risk discourses, on the one hand, reflects the perceived threats by different social actors (Mermoz, Kitzberger, \& Veblen, 2005), and on the other hand, is due to linguistic difficulties in articulating risk. Those who have experienced risk at first hand, often describe their experiences in an opportunistic way, for example, to maximize the influence on distanced political decision makers who they want to win over to their cause (Farré, 2005). This may lead to interpretations related to forest fires that are artificially exaggerated and intentionally false. Ambiguity can thus be understood as a function of conflict over preferences, intersubjectivity of discourse, and uncertainty over the technical aspects of risk communication (Hanson \& Kysar, 1999; Johansen \& Rausand, 2015). The consequential ambiguity of the discourses does not refer so much to an uncertain future as to the uncertainty related to past and present experiences.

Across all Chilean regions, the main causes of wildfires are accidents and the carelessness of man (58\%). However, almost one in three fires is caused by delinquency, in other words, intentionally caused ignitions, while $15 \%$ of the causes of fires remain in the dark. It is above all the unknown and intentional causes of wildfires that are reported and speculated on in detail in the Chilean press (Millones, 2017; see also the review of Aylwin, 2017).

Based on the statistics by the Chilean National Forest Cooperation (CONAF, 2018), Table 8.2 reveals a regionally unequal distribution of the causes of the wildfires in Chile-especially related to fires that are intentionally started. This is also strongly reflected in the causal explanations one gets when asking experts and affected parties about the background of the arsons in Chile:

1. Some argue that wildfires are caused by forest owners themselves in order to circumvent existing land-planning regulations (Caviedes, 2017). In the proximity of urban areas, for example, landowners speculate that burnt areas may be 
Table 8.2 Causes of forest fires in Chile (Annual average 2003-2016)

\begin{tabular}{lllll}
\hline & $\begin{array}{l}\text { O'Higgins } \\
\text { (VI) }\end{array}$ & $\begin{array}{l}\text { Maule } \\
\text { (VII) }\end{array}$ & $\begin{array}{l}\text { Bio Bio } \\
\text { (VIII) }\end{array}$ & \multicolumn{1}{l}{$\begin{array}{l}\text { Araucania } \\
\text { (IX) }\end{array}$} \\
\hline Annual fire events (annual average & 222 & 437 & 2,499 & 1,006 \\
2003-2016) [absolute number] & & & & \\
Causes: Accidents [\%] & 67.5 & 69.3 & 27.7 & 37.6 \\
Causes: Agricultural and forestry activities & 14.3 & 15.5 & 8.4 & 12.0 \\
[\%] & & & & \\
Causes: Arson [\%] & 14.4 & 11.0 & 35.7 & 46.5 \\
Unknown causes [\%] & 3.8 & 4.2 & 28.2 & 3.9 \\
\hline
\end{tabular}

Note. Personal elaboration with statistical data from CONAF (2018)

designated as urban developing land that awaits construction permits. This is a reality in many parts of the world (Salvati \& Ranalli, 2015). In Chile, these causes are only narratively discussed in public, since hasty accusations can have legal consequences.

2. Intentional forest fires are also interpreted as a deliberate strategy of forestry expansion. Such interpretations, in particular, arise in communities where landowners subsequently reforest burned natural forests as forest plantations (Gerber, 2011). In Chile, since the new "law on native forest recovery" (CONAF, 2008) came into force in 2008 , forest owners are prohibited from converting natural forests into forest plantations with exotic tree species. However, after a fire event, reforestation is allowed, for example, in the form of plantations with endemic species. In this way, the natural forests are made accessible and transformed for industrial exploitation (Moreno del Valle, 2015).

3. It is further argued that forest owners themselves burn their forests in order to benefit from forest fire insurances that they have purchased beforehand (Focacci, 2017). This argument in its simple form might seem plausible but most often turns out to be misleading and requires detailed and contextualized explanations: Insurers are generally very aware of the problem of the so-called moral hazard (Stiglitz, 1983), in other words, the possible deliberately caused burn of an insured forest. Therefore, insurance companies design contracts in such a way that the insured always assumes part of the risk (Agroseguro, 2018). High deductibles, for example, lower incentives to carry out fraud. Those incentives, however, can be quite different for forest owners who are on the verge of ruin, for example, in cases where an insect calamity significantly reduced the value of a standing forest so that reforestation becomes necessary. Was this the case in 2017 in certain parts of Chile's forest regions (see, e.g., the case-specific fact check in Mapuexpress, 2017)? As long as the contractual conditions that forest companies negotiate with the insurance sector are not publicly transparent, discursive and ambiguous speculation about this kind of motivation for arson will last.

4. In some cases, intentional fires in Chile are the product of deep social discontent. A widespread public opinion is that specifically in the Araucanía region, members of the Mapuche people intentionally set fires to protest against socioeconomic 
disparities and political exclusion. Wildfires seem to have become the symbol of their conflict with the Chilean state (Montalba-Navarro \& Carrasco, 2003; Rojas \& Miranda, 2015). It also seems that wildfires are directly targeted against large forestry companies that mark land uses with their tree plantations and dictate the regions' main economic activities (van Holt, Binford, Portier, \& Vergara, 2016). As late as after colonization by the Spanish, with the country's nationalization, Southern Chile experienced a capitalist appropriation and valorization of land that created vulnerable people and is still ongoing today (Latorre \& Rojas, 2016). Though the accusations are made very quickly, the circumstances of wildfires in the Araucanía region are not at all clear. Some of them turned out to have been caused by the private sector and even by public officials in order to blame the Mapuches for the crime and thus keep the conflict over land usage alive in a discursive manner (Seguel, 2018; Sepúlveda, 2013). In this way, fires serve to justify forest expansion (retrospectively) (González-Hidalgo \& Zografos, 2017).

The coexistence of these different discourses confronts political and economic actors with decision-making problems. They obscure the true motives of the actors behind the arsons, which leads to the uncertain characteristics of forest fire risk in Chile. For the insurance sector in particular, arson represents an uncertainty, in other words, risk that is impossible to calculate.

\section{Uncertainty: Hidden Self-Reinforcing Social Amplification of Forest Fire Risk}

Unknown and uncertain risks are induced by scientific uncertainty. While in the case of unknown risks researchers are aware that they do not know enough, for example, to predict the frequency and severity of catastrophic events (Chichilnisky \& Heal, 1998), uncertain risks remain hidden from the society's radar for a long time (Beck, 1992; O'Malley, 2004). This is partly due to the fact that the causes of modern risks-but also their effects-are no longer confined to one place. Often there is also no legally identifiable entity as the perpetrator of risk. Risk decisions can have a long latency period before they materialize. For political actors, this is the main source of uncertainty: "[I]t is precisely unknown unknowns which provoke far-reaching conflicts over the definition and construction of political rules and responsibilities with the aim of preventing the worst" (Beck, 2006, p. 335).

Researchers also refer to uncertainty in risk to address processes of systemic, self-reinforcing risk amplification (Kaufman \& Scott, 2003). Uncertain risks are systemic if they trigger unnoticed chain reactions. Accumulated negative externalities can trigger devastating effects. In the following, I will focus on three examples of systemic aspects of uncertainties related to wildfire risk in Chile. They raise awareness of the fact that depending on the local and regional context, the occurrence of a forest fire in Chile can "ignite" subsequent fires and reinforce risk. The first example is certainly simplified, but it serves as a textbook example to illustrate 
the underlying systemic effect empirically. In the second example I refer once again to the discussion of the ambivalent symbolic attributions of arson that I introduced in the previous chapter. In the third example I summarize a content-analytical interpretation of interview statements from several empirical field studies in the Maule region conducted between 2015 and 2019.

1. In individual and isolated cases in Chile, it turned out that wildfires were deliberately caused by young people "[...] to experience once again the spectacular use of airplanes or helicopters in the firefighting process" (interview with forest firefighters in Constitucion/Maule, 2015). This problem seems particularly relevant in the transition zone between urban and forested areas. The legitimate concern of this type of wildfire causes is also reflected in rulebooks that guide fire brigades (Vélez, 2009). Pragmatic rules stipulate that helicopter missions in the event of fire should be restricted to areas outside urban areas. This may be understood as aimed at preventing the experienced spectacles of past fires from causing new fires in the future.

2. Another systemic aspect of risk is evidenced in the strategic appropriation of the symbolic effects that fire and flames can create (Segovia, Basulto, \& Zambrano, 2018). As a social imaginary, forest fires acquire effectiveness for different groups in the Chilean society-even if they live far away from forested areas. Fires are lit repeatedly due to their medial efficacy and the sociocritical imaginations originating from them, and as was demonstrated in the previous chapter, these imaginations are ambiguous in Chile. For some, they represent the struggle of the vulnerable against the neoliberal alliance between the state and the industrialized forestry business. For others, they gain importance in justifying that the State takes sides and imposes even harsher control over resource peripheries (see also Chap. 16 by Hayter and Clapp). Different groups expect individual advantages from wildfires. The risk transcends the boundaries of systems when its effects extend from the forest landscape to the economic and political spheres (see also Beck, 2006).

3. In the Maule region, where one might not expect it at first because there has been no open conflict over land use so far, forest fires have recently created a systemically heated atmosphere that has the potential to further increase the inherent risks. The explanations behind this case are as follows: Competition in the regional timber market in Maule is fierce. Within a radius of $30 \mathrm{~km}$ of Constitución, about 60 small and medium-sized family owned sawmills compete with each other for access to raw timber resources. Some work as contractual suppliers for the large forestry companies in the region and thereby gain privileged access to their clients' timber resources. Others have emancipated themselves from the big players in search of their own customers. In the course of time, they also have acquired their own forest property, which, however, is not sufficient to supply them with raw materials all year round. They experience that their expansion opportunities are limited by the supply of regional timber that turns out to be scarce and sensitive in price - a situation that has worsened since 2017 
(Hechavarria, 2018). This is an important first detail in understanding the regional conflict and the subliminal systemic risk of forest fires that accumulates in the Maule region.

Speculation and mutual accusations on the causes of recent wildfires spread in the region: Large forest owners, for example, claim that their smaller neighbors act as free-riders in the face of forest fire risk. In other words, "[...] they do not buy insurance and [instead] rely opportunistically on the fact that their forest property is observed and cared for by the large company and their fire brigades" (Interview conducted with the manager of a medium-sized sawmill in San Ramón, March 10, 2016). This expectation would-according to the interviewee-reduce smaller landowners' incentives to actively monitor their plantations. From the point of view of large forest owners, this increases the risk of a forest fire in their neighborhood and therefore "[...] through geographical expansions, the risk of damage to our plantations is uncontrollably increased" (Interview conducted with the operational risk manager of a large forest company in Constitution, March 11, 2016). Implicitly, this deep concern of the large company gives rise to the carelessness of the small neighbors in the first place.

According to this logic, it is understandable that large forest owners in Chile have incentives to expand their forest ownership over a large area and in a coherent manner: The less mixed the regional mosaic of forest properties, the more controlled the risk will be (Vergara-Díaz, Sandoval-Vásquez, \& Herrera-Machuca, 2017). In response to the discourses of the large companies that accuse small landowners of being opportunistic, these, in contrast, accuse the big players of not adequately protecting the property of their neighbors in the event of a forest fire. More precisely, in interviews with medium-sized forest owners in Maule in 2016, large forestry companies were accused of directing fire fronts towards the property of small forest owners to avoid major damage to their own forest plantations. Still others claim that extensively insured forest areas stand in the way of the real efforts of large forestry companies to fight the flames. Of course, it is not possible within the framework of this contribution to resolve the absolute truth behind these testimonies or to confront it with the technical aspects of firefighting. It should be noted, however, that firefighting follows military hierarchical command structures and, depending on the situation, includes the right to subordinate private property, which is otherwise very strongly protected in Chile. At least the narratives presented above give an idea of the subliminal conflict between small and large forestry actors in the Maule region. The fear of pyromaniac acts in the region in response to economic repression and exclusion is growing for years (see also the statements of economic actors quoted in Saavedra, 2017). ${ }^{4}$

\footnotetext{
${ }^{4}$ In more recent interviews with forest owners in the Maule region, implications of the arsonists of the 2017 forest fires were collectively avoided. "We don't want to make any false accusations, and in particular we want to hinder the discourses from Chile's southern forest regions to reach the Maule region. We want to avoid the false interpretation that forest fires have become an inflicted result of the forest industry itself," one sawmill owner openly admitted in an interview early in 2019.
} 
Systemic risks are uncertain until they materialize and therefore cannot be calculated ex ante (Ilin \& Varga, 2015). To address them, a readjustment of risk perception is needed. In the first case, this was done, as described, by new firefighting rules that limit the use of actually effective helicopters to specific areas. In the second case, however, the systemic effect of risk remains out of reach for risk managers in forestry. At best, they have the option of relying on risk-avoidance strategies - that is to distance themselves from the neoliberal model of forestry-, which in this case could mean the end of their business model; and even that does not guarantee that other actors will not continually try to exploit the symbolic effect of forest fires. The interviews quoted for the third case show that regional economic actors at least develop a feeling for the accumulating systemic risk.

As should have become clear from the above, the epistemological challenges of the complexity, ambiguity, and uncertainty of forest fire risk arise from the fact that all three characteristics are closely intertwined and lead to an obscuring of risk relationships. Against this background, it is understandable that risk managers usually aim at simplifying and separating the individual attributes of risk. This enables them to transform ambiguity or uncertainty into complexity that they can then structure and handle by making use of technical risk models (Ericson \& Doyle, 2004). In the following chapter, I explain how this works in practice. While it becomes clear that risk management is not the same as risk governance, the chapter reveals the complementary aspects of different management practices and explores their possible uses in explicitly regional risk governance approaches.

\section{The Complementarity of Risk Management Practices}

Advocates of theoretical insights from the New Institutional Economics (Furubotn \& Richter, 2005), which are widely applied in financial risk management practices, proclaim markets and hierarchies as in a sense ideally opposed governance forms for the coordination of economic interaction. The characteristics of a transaction as well as the degree of asymmetrically distributed information between economic actors determine whether either hierarchical orders through company routines or market-based pricing processes under competitive conditions provide transactioncost-efficient coordination. Interestingly, hierarchical and market-based forms of risk management are not necessarily opposed to each other, but rather mutually supportive. The case of risk-management practices in Chile's forestry sector illustrates that a hierarchically organized risk management even can be the prerequisite for the emergence of and access to insurance market solutions.

To fully understand the complementary logic behind these practices, it is important to note that forestry companies and insurers only slightly differ in their basic approach to risk and uncertainty. Both actors are able and willing to handle risk that they can calculate by themselves, and both reject uncertainty in risk management. Then, however: What can a market for forest fire insurances look like if the preferred and undesirable risks of both players are more or less the same? Of course, it 
depends on the small differences in dealing with particular characteristics and aspects of risks. Additionally, one has to look at the uncertainty avoidance strategies of both actors to understand the complementary character of Chilean forest fire risk management practices.

For insurance companies, calculated risks undisputedly represent a core business. Insurers are able to diversify them with the help of the law of large numbers, which states that the empirical reality (temporal and spatial) of risk can be aggregated into mean values (Chichilnisky \& Heal, 1998). Forestry companies take a positive view on risks as well. Correctly managed, risks promise above-average returns and competitiveness advantages (Lundqvist, 2015). In contrast to insurers, however, forestry companies have to find ways to handle causes and effects of forest fires individually and in context-specific ways.

Uncertainty, that is incalculable risk, is something that neither actor is looking for. Forestry companies and insurers alike are trying to externalize or completely avoid risks that are rare (and at the same time very destructive), highly specific, and uncertain. Large forestry companies in particular, as I showed in the previous chapter with the example of systemic forest fire risks in Maule, are afraid of risks that "are taken" independently and opportunistically by others and that "endanger" the success of their own businesses in the sense of a negative externality (Luhmann, 1991/1993). Insurance companies, in turn, do everything to avoid moral hazard behavior of their clients, which can even lead to the situation that there is no market supply for insurances at all (Hellwig, 1983; Stiglitz, 1983). This line of argumentation fits with the transaction-cost approach, whose advocates stipulate purely hierarchical control for dealing with uncertain risks (see also Knight, 1921). How does the insurance market emerge when market participants share a common desire to waive or avoid uncertainty? The answer has to do with diverse risk management practices of standardization and categorization of risk in order to reduce its complexity, ambiguity, and uncertainty characteristics.

\section{Risk Management in Chilean Forestry}

In Chile's industrialized forestry sector, forest plantations are managed in a way that minimizes both the likelihood of a forest fire and the possibility of uncontrolled expansion. The homogenization of contextual conditions, the simplification of risk relationships, and the decoupling of certain risk elements go hand in hand and influence each other reciprocally: (i) The simplification of risk begins with the focus on certain causes of forest fires. In particular, the main cause of accidents can be minimized through employee training and clear routine instructions. Routines are instrumental for the implementation of plantation management practices that aim at creating industrial economies of scale. Only a few specialists are needed to monitor the compliance of the routines. (ii) The decoupling of forest fires' causes and effects is achieved through targeted infrastructure investments, such as the formation of firebreaks that slow down or stop fires that have broken out. Often, firebreaks are 
strategically created in the course of regular clear cuts. In this case, plantation management practices and infrastructure investments coincide. Furthermore, forest roads are a strategic investment that serves risk management purposes as they allow fire brigades quick access. (iii) Finally, the homogenization of the physical space complements the decoupling and simplification of risk relationships. The large forestry companies in Chile aim at a consolidated and coherent forest property. Over the past 40 years, they have achieved this largely through continuous acquisitions and forestation of tree plantations. Only few other private forest properties still separate the plantations of the large companies. Connected forested areas lead to economies of scale in forestry logistics. They can also be better monitored with fire protection watchtowers, which in turn further contribute to the decoupling of risks as fires can be quickly detected once they have broken out.

All these plantation management practices are based on combining centralized and decentralized risk management logics. In addition, multiple spatial references are evident: Complexity reduction via routines, for example, is planned and coordinated hierarchically top-down from the companies' headquarters (see also Perrow, 1986). The site-specific implementation and monitoring of the routines, however, takes place in decentralized way. The watchtowers in the forest regions are an important node in the risk communication network. In case of a forest fire, their occupants communicate to neighboring units and the company headquarters alike so that responses can strategically be elaborated in a timely manner. In the event of a wildfire, military-like chains of command are activated and take control. Firefighters are coordinated centrally but can decide locally in order to be able to react quickly to changing conditions (Arnaldos, Navalón, Pastor, Planas, \& Zárate, 2004). With this combination of centralized and decentralized risk-management routines, actors in forestry enterprises are in a good position to react to ambiguous risk signals from forest regions and actively shape local practices of handling risk. However, through locally adapted action, they are also coresponsible for creating ambiguity in the interpretation of wildfire risks in Chile on a national scale.

\section{Risk Management in Insurance Companies}

Insurance companies implement risk management practices that rely on standardization and categorization based on quantification and mathematical procedures (Dean et al., 2003; Jarzabkowski, Bednarek, \& Spee, 2015). Since quantification disconnects existing data from local narratives or general stories that stabilized the meaning of risk in the first place (Müller-Mahn et al., 2018), insurance companies must create their own meanings of risk. Prices in insurance markets, for example, are such a standard for risk quantification that also provides meaning for economic operations (Hayek, 1945; Kessler, 2015). Prices communicate the magnitude of the risk to third parties such as policyholders. Risk maps provide a similar communication frame (Dransch, Rotzoll, \& Poser, 2010). Maps not only can be used to locate the origins of historical forest fires events and illustrate their propagation in space. 
Loss statistics incorporated into the maps also provide insurers with a spatial overview of the risk's frequency and extent. Risk maps, therefore, serve marketing purposes. Insurance companies use them to signal to their clients why insurance policies in so-called high-risk areas contain a high insurance premium. Risk maps give meaning to prices. This kind of risk communication, however, first requires a sophisticated valuation process (Aspers, 2009). Risk valuation applied in insurance companies' risk management practices is mainly based on mathematical models and correlation logics. Actors using these models are able to capture the complexity of individual aspects and conditions that cause or amplify forest fires and break them down into their individual components by means of multiple (and even spatial) regressions (Castro \& Chuvieco, 1998). Spatially differentiated risk models allow insurers to simulate their values at risk.

The better the insurance company manages to break down the complexity of wildfires into modeled chains of linear causes and effects, the better it can design and offer different kinds of insurance contracts. On the one hand, insurance companies are always free to decide whether and where to offer an insurance policy to a customer. This means that they can exclude areas in which forest fires occur very frequently and for unknown reasons from accessing insurance. The market is simply rationed geographically (Hellwig, 1983). On the other hand, insurance companies have a strong contract design tool at their disposal: self-selection (Furubotn \& Richter, 2005). By offering customers alternative contract designs that differ, for example, in the amount of the deductible in the event of a loss, insurers obtain detailed information about a customer's risk exposure. By accepting certain contracts and rejecting others, the insured reveals his risk attitude and self-assesses his exposure to risk. Self-selection is part of a bilateral negotiation process. In negotiations, the customers themselves offer to fulfill certain conditions in order to lower the prices for insurance. For example, the better the forestry company itself controls the risk through simplification, homogenization and decoupling its effects, the cheaper the insurance premium offered.

\section{Mutually Complementary Risk Management Practices and Risk Avoidance Strategies}

The hierarchical and market-oriented risk management practices of forestry companies and the Chilean insurance sector complement each other at least in two ways: On the one hand, this can be seen from the fact that forestry management practices stimulate innovation in insurers' services. Without economies of scale from industrialized plantation management, the market for forest fire insurance in Chile would have been too small, too transaction-intensive, and possibly nonexistent (see also 
Chichilnisky \& Heal, 1998). ${ }^{5}$ On the other hand, complementarity most obviously arises from how insurers influence the forestry management standards of forestry companies through self-selection and contract design. Insurers make it clear how important it is for them that hierarchically supervised forestry workers regularly thin out the plantations (= simplification of risk correlations), that the insured plantations comprise a minimum size (= homogenization of risk), and that watchtowers and firebreaks cover areas at risk (= decoupling of risk correlations). These requirements are either specified directly in the insurance contracts, or the forestry companies are indirectly given incentives to fulfill them through promised premium discounts.

Self-reinforcing effects of hierarchical and market forms of risk management also derive from the uncertainty avoidance strategies of the actors. Forestry companies, for example, want to get rid of the unlikely but in principle possible scenario of a total loss of their assets in the event of a regional wildfire catastrophe. Although they view this total loss scenario as unacceptable, it is also incalculable and therefore incorporates the characteristics of uncertainty. Large forestry companies avoid this uncertainty by transferring it to the insurance sector. They buy insurance policies that include high deductibles. As a result, despite having invested in insurance, the forestry companies will cover many minor losses by themselves. This practice is confirmed by the operational risk manager of a large Chilean forestry company: "Even in the disaster year 2017, the compensation payments of our insurers were below the expenses of the annual insurance premiums. All our contracts included high deductibles" (Personal interview conducted in 2018). The manager claimed that the firm's shareholders explicitly wished to insure only the uncertainty of a total loss.

What forestry companies consider an incalculable and uncertain risk, caused by third parties and therefore understood as an external hazard, is, in the eyes of the insurer, complex and controllable. Insurance companies are able to absorb the uncertainty of a total loss of one of their customers because they can diversify it and convert it into a calculable and statistically low risk of a total loss across all their customers. However, insurers also retain much of their control over risk explicitly through their own uncertainty avoidance strategies: They avoid uncertainty by rationing the market. This strategy is geographically oriented in two ways: On the one hand, as already mentioned, they exclude insurance in municipalities with high potential for political tension, in other words, in territories where arson is a frequent cause of forest fires or where causes are simply unknown. On the other hand, they also exclude specific forest areas on a small scale that they declare to be uninsurable. In avoiding so called cluster risks and risks of geographical contagion, insurers deny market access to forest owners located in the immediate geographical proximity of already insured forest property. During a 2016 interview, a Chilean insurance company's sales executive referred to a map on the wall of his office, on

\footnotetext{
${ }^{5}$ This is illustrated, for example, by the fact that there are currently no insurance policies available for economically used natural forests.
} 
which the sites of the currently insured forest areas in his responsibility were marked with flags. These markings gave the sales executive an indication of the surrounding areas where he could (or should) not offer any further forest fire insurance. "I avoid selling here because a single forest fire could otherwise affect several of my customers at the same time," he explained. In a market like Chile, which is characterized by a limited number of insurers (Loewe et al., 2017), this leads to the exclusion of forest owners willing to buy insurances. Rationing financial products is typical for oligopolistic insurance markets (Hellwig, 1983). However, for some clients of the insurance companies, exclusion may seem arbitrary. Even when exclusion is based on the principle of who comes first, for many it seems related to an exclusive relationship between the insurers and the large Chilean forestry companies. In some ways, geographically uneven access to insurance in Chile represents a negative externality of insurance-based risk management practice and can be interpreted as the result of the decontextualization of risk and risk knowledge, which I will explain in more detail in the following chapter.

\section{The Decontextualization of Risk and Risk Knowledge}

Risk managers tend to analyze different risks in isolation (MacKenzie, 2011). In more general terms, risk-exposed actors epistemologically grasp and handle the causes and effects of risks as if they were separated from each other (Rosa et al., 2014). Therefore, also conceptually it makes perfect sense to separate the material dimension of potential physical losses from the discursive dimension of how people originally perceive, communicate and socially construct risk. However, in the course of these management and academic practices, the knowledge of risks is easily decontextualized, also in a spatial sense (November, 2008).

Forestry and insurance companies in Chile design and work with economic models for decision making that are considered (and have been proven) to be useful for the handling of risk. In doing so, they clearly decontextualize the risk of forest fires in a spatial sense. Forestry enterprises, for example, decontextualize risk and risk knowledge in the course of their homogenization and standardization strategies in managing forested land. They homogenize space by purchasing adjacent areas, which they then use for reforestation, and they standardize space by anchoring the same risk management routines in their plantations. Actors using routines not only standardize risk knowledge, they also decouple risk from the unit of space, in the course of which plantation forests are transformed into assets that can be valued uniformly and according to economies of scale. A forest area managed as a monoculture decontextualizes specific site conditions. It ignores the fact that site-adapted, native tree species might be superior to exotic tree species in terms of reducing the local risk of forest fires.

The decontextualization of knowledge related to forest fire risks can also be seen in the fact that large forestry companies even succeed in acquiring insurance for their plantations in politically unstable communities, in other words, in 
communities in which insurance companies are actually planning a rationing strategy for the market. Large forestry companies generally own and manage forest areas spread over several forest regions in Chile, and because these are homogenized and managed in a standardized and comparable manner, they are able to acquire a package of insurance policies from the insurance companies that covers several separated plantations at once. Forest fire risks in high-risk areas are then contractually offset by risks in less endangered areas. The exact knowledge of the circumstances of the risk in the package becomes blurred and decontextualized. It no longer appears relevant due to the standardized price for the packaged risk.

By purchasing an insurance package with spatially dispersed forest ownership, also the insurer gains several advantages. Not only does a package of insurances enable the application of the law of large numbers; the insurer is also given an opportunity to spread the risks spatially, which reduces his risk of total failure. His accumulated overall risk is no longer determined by the conditions at a given site. This reduces his interest in surveying context-specific knowledge about the exact causes and effects of individual forest fires. The same is true for a high number of deductibles that policyholders accept in individual insurance contracts. Finally, the decontextualization of risk increases its quantifiability, which enables the insurer to translate it into the language of the financial markets, which in turn opens up opportunities for the insurer to resell parts of the risk to reinsurance companies.

Despite all these obvious advantages for corporate risk-management practice, the widespread practice of decontextualizing risk and knowledge on forest fire risks in Chile, coupled with reduced incentives to generate new knowledge, for example about the causes and effects of forest fires, can prove to be a step backwards in governing risk from the point of view of a resilient society. Uncertainties and ambiguities require a broadening of the risk debate and should include as many stakeholders in the evaluation process as reasonable: "Participants should be asked to find a consensus of the extra margin of safety in which they would be willing to invest in exchange for avoiding potentially catastrophic consequences" (Rosa et al., 2014, p. 144). Risk assessments that are based on economic considerations alone are accompanied by disparities. If the initial conditions for decision making on risk are not equally distributed among societal actors they open the window for selfreinforcing processes of systemic risk accumulation.

\section{Conclusion}

Forest fire risks in Chile have different spatiotemporal origins and consequences. They prove to be epistemologically complex, ambiguous, and uncertain depending on the socioeconomic and sociopolitical context of their appearance. Different physical and anthropological causes and effects of forest fires cannot be clearly attributed (= complexity). Unexplained causes give rise to various logical explanations, which run counter to each other (=ambiguity) and hamper collective efforts to deal with the risk. In many cases, actors also demonstrate a lack of sensitivity to 
their own risk unawareness (=uncertainty). In sum, the knowledge about the causes and effects of wildfires in Chile is heterogeneous and geographically dispersed among societal actors. Empirically it becomes evident that wildfire risks in Chile are socially constructed. They depend on how findings from natural and social science are interpreted and being implemented in standards of risk management practices. These practices also communicate risk, as in the present case via prices and access to insurance markets.

Focusing on economic-geographical explanations, in this study I have not only made it clear that forest fires are a profoundly geographical risk, but also that they represent a fundamentally collective challenge for Chilean forest regions. A single fire-regardless of its origin — can affect and destroy the forest property of neighboring actors. Accordingly, neighborhood relationships, in other words, cooperative and collective approaches to risk management practices, could have been expected. However, it turned out that forestry enterprises prefer to organize risk management on an individual basis, applying hierarchical company routines. In parallel, they buy insurance policies to transfer part of the risk to the financial markets. Their relationships with insurance companies are based on bilaterally negotiated contract designs and market prices for risk.

Forestry companies and insurance companies in Chile seem to have found a complementary way of dealing with risk by sharing jointly created technical risk knowledge as part of their routine risk-management practices. Both choose a management approach that reduces complexity, decouples risk, and decontextualizes risk knowledge to make forest fire risks calculable and manageable in mutually beneficial ways. They agree, on the one hand, on price mechanisms for insurance contracts as a standardized language, which has the consequence that detailed geographical knowledge on forest fire risks in Chile is explicitly decontextualized and reduced. On the other hand, they follow complementary risk-avoidance strategies whenever risks are characterized as ambiguous or uncertain.

The catastrophic forest fires in 2017 revealed the limits of standardized risk management practices. The law of large numbers and therefore the calculability of risk, in general terms, becomes less effective when large and unlikely events occur or when the causes of the risks are systemically interdependent. The latter is the worst case for the insurance business. Systemic interdependencies of risks can hide behind characteristics of ambiguity or uncertainty. In addition, there is a great danger that if actors only follow their own dominant risk discourses and ignore observations and interpretations that are due to different conditions of the spatiotemporal context of risk, the dynamic changes in the relationships between environmental and anthropogenic risk factors of forest fires in Chile remain invisible to decision makers. The catastrophic extent of the forest fires of 2017 can certainly be attributed first and foremost to the extreme climatic conditions. However, there are also numerous indications that the fires were ignited by arson across a broad front. Unfortunately, their exact background remains unknown to this day (Saavedra, 2017).

This calls for a coordinated effort of risk management that gives regional knowledge an explicit edge and is designed as a long-term learning process. Risk management primarily covers individual views of risk. In contrast, risk governance offers a 
holistic approach that assigns the social responsibilities of risk takers and also considers negative externalities for other societal stakeholders in spatiotemporal variation. Of course, this does not mean that risk management has no value at all. The risk governance concept of the International Risk Governance Council, an international think tank that aims at improving the understanding and assessment of risk and the ambiguities involved, integrates risk management into a larger process of risk governance. Risk communication, which includes the transmission of risk data, but also the transfer of sophisticated risk knowledge forms the connecting link in the governance process, which is circular and reflexive by nature (Renn, 2008, p. 374). Risk governance practices take the attributes of ambiguity and uncertainty in risk knowledge into account and open debates on risk that invite many societal stakeholders to take part in risk evaluation and risk assessment processes. In particular, risk governance is about transparency, which enables collective learning for a more resilient risk society.

Researchers must take the complexity, ambiguity, and uncertainty of knowledge on forest fire risks in Chile seriously. These attributes originate from social science perspectives on risk. Empirically, one cannot always separate them from each other, which is why they cannot have the objective of structuring risk governance uniformly. However, their transparent application in risk management or risk governance has consequences. The comparative clarification of the attributes communicates to society how risk is defined and legitimized in the future (see Bustos, Lukas, Stamm, \& Torre, 2019, for a similar argument related to regional crisis management in Chile). A lack of societal participation and acceptance of normative settings can lead to adverse reaction and resistance (see, e.g., the case study on forest fires in California by Simon \& Dooling, 2013).

Since forest fires are immanently spatial, the regional level promises to be a suitable scale for initializing the organization of related risk governance processes. At the regional level, changing interrelationships in risk formation can be observed and interpreted early on (Müller-Mahn et al., 2018). However, as I have shown with my statements and empirical analyses in this contribution, forest fire risks can be technically detached from the spatial dimension, especially in terms of their economic effects. Decontextualization is what makes it possible to deal with risk financially in first place. In Chile, it gave rise to a reciprocal complementary relationship between hierarchy and market forms of risk management. Are these complementarities valuable for risk governance approaches as well? Some of the knowledge and guidance on certain risk management practices on the regional scale come directly from the insurance sector. Insurers utilize contract design and negotiations to offer direct and indirect incentives to decouple wildfire risks and learn how to manage them in a routinely manner. However, the extent to which different forms of risk management practices complement each other in a regional context of risk governance and lead to a higher level of local-global knowledge that strengthens the resilience of the society in the long term remains a pending issue that requires additional research efforts beyond the example of forest fires in Chile. 


\section{References}

Agroseguro. (2018). Seguro de explotaciones forestales: Condiciones [Forestry insurance: Conditions]. Retrieved from https://agroseguro.es/fileadmin/propietario/Productos/ FORESTALES/319\%20INCENDIOS\%20FORESTALES/PLAN_2018/CES-319-18-1.0.pdf

Altamirano, A., Salas, C., Yaitul, V., Smith-Ramirez, C., \& Ávila, A. (2013). Influencia de la heterogeneidad del paisaje en la ocurrencia de incendios forestales en Chile Central [Influence of landscape heterogeneity on the occurrence of forest fires in Central Chile]. Revista de Geografía Norte Grande, 55, 157-170. https://doi.org/10.4067/S0718-34022013000200011

Arnaldos, J., Navalón, X., Pastor, E., Planas, E., \& Zárate, L. (2004). Manual de ingeniería básica para la prevención y extinción de incendios forestales [Engineering manual for the prevention and extinction of forest-fires]. Madrid: Mundi-Prensa.

Aspers, P. (2009). Knowledge and valuation in markets. Theory \& Society, 38, 111-131. https:// doi.org/10.1007/s11186-008-9078-9

Aylwin, J. (2017, February 7). Incendios y modelo forestal: Una estrecha relación [Wildfires and the forestry model: A strong relationship] [Opinion]. The Clinic (Santiago de Chile). Retrieved from https://www.theclinic.cl/2017/02/07/ columna-jose-aylwin-incendios-modelo-forestal-una-estrecha-relacion/

Barton, J. R., \& Román, Á. (2012). Social movement strategies for articulating claims for socioecological justice: Glocal asymmetries in the Chilean forestry sector. Globalizations, 9, 869-885. https://doi.org/10.1080/14747731.2012.739346

Beck, U. (1992). Risk society: Towards a new modernity. London: SAGE. (Original work published 1986)

Beck, U. (2006). Living in the world risk society. Economy and Society, 35, 329-345. https://doi. org/10.1080/03085140600844902

Becker, M. C., \& Knudsen, T. (2005). The role of routines in reducing pervasive uncertainty. Journal of Business Research, 58, 746-757. https://doi.org/10.1016/j.jbusres.2003.10.003

Beckert, J. (2016). Imagined futures: Fictional expectations and capitalist dynamics. Cambridge, MA: Harvard University Press.

Bottaro, G., Roco, L., Pettenella, D., Micheletti, S., \& Vanhulst, J. (2018). Forest plantations' externalities: An application of the analytic hierarchy process to non-industrial forest owners in central Chile. Forests, 9, 141-162. https://doi.org/10.3390/f9030141

Brugnach, M., \& Ingram, H. (2012). Ambiguity: The challenge of knowing and deciding together. Environmental Science and Policy, 15(1), 60-71. https://doi.org/10.1016/j.envsci.2011.10.005

Bustos, B., Lukas, M., Stamm, C., \& Torre, A. (2019). Neoliberalismo y gobernanza territorial: Propuestas y reflexiones a partir del caso de Chile [Neoliberalism and territorial governance: Proposals and reflections based on the case of Chile]. Revista de Geografía Norte Grande, 73, 161-183. https://doi.org/10.4067/S0718-34022019000200161

Cabantous, L. (2007). Ambiguity aversion in the field of insurance: Insurers' attitude to imprecise and conflicting probability estimates. Theory and Decision, 62, 219-240. https://doi. org/10.1007/s11238-006-9015-1

Castillo, M. E., Molina-Martínez, J. R., Rodríguez y Silva, F., \& Julio, G. H. (2013). A territorial fire vulnerability model for Mediterranean ecosystems in South America. Ecological Informatics, 13, 106-113. https://doi.org/10.1016/j.ecoinf.2012.06.004

Castro, R., \& Chuvieco, E. (1998). Modeling forest fire danger from geographic information systems. Geocarto International, 13, 15-23. https://doi.org/10.1080/10106049809354624

Caviedes, J. A. (2017). Construyendo sobre cenizas: ¿Son utilizados los incendios forestales como una herramienta informal para la expansión urbana de Chile central? [Building on ashes: Are forest fires used as an informal tool for urban expansion in central Chile?] (master's thesis). Pontificia Universidad Católica de Chile, Santiago de Chile. Retrieved from http://estudiosurbanos.uc.cl/images/tesis/2018/MHM_JonathanCaviedes.pdf 
Chichilnisky, G., \& Heal, G. M. (1998). Managing unknown risks: The future of global reinsurance. The Journal of Portfolio Management, 24, 85-91. https://doi.org/10.2139/ssrn.1375656

Cifuentes, R., Desormeaux, J., \& González, C. (2002). Capital markets in Chile: From financial repression to financial deepening. BIS Papers, 11, 86-102. Retrieved from https://ideas.repec. org/h/bis/bisbpc/11-06.html

Clapp, R. A. (1995). Creating competitive advantage: Forest policy as industrial policy in Chile. Economic Geography, 71, 273-296. https://doi.org/10.2307/144312

Clark, G. (2018). Learning-by-doing and knowledge management in financial markets. Journal of Economic Geography, 18, 271-292. https://doi.org/10.1093/jeg/lby005

CMPC [Compañía Manufacturera de Papeles y Cartones]. (2018). Integrated Report CMPC 2017. Retrieved from https://s23.q4cdn.com/927837516/files/doc_financials/annual/IntegratedReport-2017.pdf

CONAF [Corporación Nacional Forestal]. (2008). Ley sobre recuperación del bosque nativo y fomento forestal y reglamentos [The Chilean law of recuperation of native forest and forestry promotion]. Retrieved from http://www.conaf.cl/wp-content/files_mf/1368741650LibroLey_ Bosque_NativoReglamentos.pdf

CONAF [Corporación Nacional Forestal]. (2017). Descripción y efectos 'tormenta de fuego': 18 de enero al 5 de febrero de 2017, regiones O’Higgins, el Maule y Biobío [Characteristics and effects of the fire-storm 2017]. Retrieved from http://www.conaf.cl/tormenta_de_ fuego-2017/DESCRIPCION-Y-EFECTOS-TORMENTA-DE-FUEGO-18-ENERO-AL-5FEBRERO-2017.pdf

CONAF [Corporación Nacional Forestal]. (2018). Statistics published on the website. Retrieved from http://www.conaf.cl/centro-de-documentacion/

Crang, M. (2002). Qualitative methods: The new orthodoxy? Progress in Human Geography, 26, 647-655. https://doi.org/10.1191/0309132502ph392pr

Crouch, C., \& Keune, M. (2012). The governance of economic uncertainty: Beyond the "new social risks' analysis. In G. Bonoli \& D. Natali (Eds.), The politics of the new welfare state (pp. 45-67). Oxford, UK: Oxford University Press. https://doi.org/10.1093/acprof: oso/9780199645244.003.0003

Dean, B., Doyle, A., \& Ericson, D. (2003). Insurance as governance. Toronto, Canada: University of Toronto Press. https://doi.org/10.3138/9781442676220

Dransch, D., Rotzoll, H., \& Poser, K. (2010). The contribution of maps to the challenges of risk communication to the public. International Journal of Digital Earth, 3, 292-311. https://doi. org/10.1080/17538941003774668

Eisenhardt, K. M. (1989). Building theories from case study research. The Academy of Management Review, 14, 532-550. https://doi.org/10.2307/258557

Ericson, R. V., \& Doyle, A. (2004). Uncertain business: Risk, insurance, and the limits of knowledge. Toronto, Canada: University of Toronto Press.

Farré, J. (2005). Comunicación de riesgo y espirales del miedo [Risk communication and spirals of fear]. Comunicación y Sociedad, 3, 95-119.

Flick, U. (2018). An Introduction to qualitative research. London: SAGE.

Focacci, G. (2017, July 4). Investigan relación de incendios forestales con plaga de avispas y pago de seguros [Investigation of the relationship between forest fires, wasp infestation and insurance payments]. biobiochile.cl (Chile). Retrieved from https://www.biobiochile.cl/noticias/ nacional/chile/2017/07/04/investigan-relacion-de-incendios-forestales-con-plaga-de-avispasy-pago-de-seguros.shtml

Freeman, P. K., \& Kunreuther, H. (1997). Managing environmental risk through insurance. Studies in Risk and Uncertainty: Vol. 9. Dordrecht: Springer. https://doi. org/10.1007/978-94-011-5360-7

Furubotn, E. G., \& Richter, R. (2005). Institutions and economic theory: The contribution of the new institutional economics (2nd ed.). Ann Arbor, MI: The University of Michigan Press. https://doi.org/10.3998/mpub.6715 
Gatica, F. (2012). Prácticas empresariales con potencial de vinculación territorial: El caso del sector forestal chileno [Business practices embedded in territories: The case of the Chilean forestry sector]. Revista de Geografía Norte Grande, 52, 127-143. https://doi.org/10.4067/ S0718-34022012000200008

Gerber, J.-F. (2011). Conflicts over industrial tree plantations in the South: Who, how and why? Global Environmental Change, 21, 165-176. https://doi.org/10.1016/j. gloenvcha.2010.09.005

Glückler, J., Rehner, J., \& Handke, M. (2019). Gobernanza, redes y territorio: Editorial [Governance, networks and territory: Editorial]. Revista de Geografía Norte Grande, 74, 5-20. https://doi.org/10.4067/S0718-34022019000300005

Gobierno de Chile. (2017). Chile y la "tormenta de fuego": Informe incendios forestales-EneroFebrero de 2017 [Chile and the "firestorm": Report on forest fires-January-February 2017]. Santiago de Chile: Ministerio del Interior y Seguridad Pública. Retrieved from http://biblioteca.digital.gob.cl/bitstream/handle/123456789/64/2017-03-29\%20Chile\%20y\%20la\%20 Tormenta\%20de $\% 20$ Fuego $\% 20-\% 20$ final $\% 20-\% 20$ para\%20distribucion\%20limitada.pdf?seq uence $=1 \&$ isAllowed $=\mathrm{y}$

Goméz-González, S., \& Espósito, R. C. (2017). Debate sobre las causas de los incendios forestales en Chile [Debate on the causes of forest fires in Chile]. Revista Mundo Forestal, 32, 16-29. Retrieved from http://cifag.cl/wp-content/uploads/2017/08/RM32_baja-1.pdf

Gómez-González, S., González, M. E., Paula, S., Díaz-Hormazábal, I., Lara, A., \& DelgadoBaquerizo, M. (2019). Temperature and agriculture are largely associated with fire activity in Central Chile across different temporal periods. Forest Ecology and Management, 433, 535-543. https://doi.org/10.1016/j.foreco.2018.11.041

González, M. E., Gómez-González, S., Lara, A., Garreaud, R., \& Díaz-Hormazábal, I. (2018). The 2010-2015 megadrought and its influence on the fire regime in central and south-central Chile. Ecosphere, 9(8), Article e02300. https://doi.org/10.1002/ecs2.2300

González-Hidalgo, M., \& Zografos, C. (2017). How sovereignty claims and "negative" emotions influence the process of subject-making: Evidence from a case of conflict over tree plantations from Southern Chile. Geoforum, 78, 61-73. https://doi.org/10.1016/j. geoforum.2016.11.012

Hacking, I. (1990). The taming of chance. Ideas in Context: Vol. 17. Cambridge, UK: Cambridge University Press. https://doi.org/10.1017/CBO9780511819766

Hanson, J. D., \& Kysar, D. A. (1999). Taking behavioralism seriously: The problem of market manipulation. New York University Law Review, 74, 632-749.

Hayek, F. A. (1945). The use of knowledge in society. The American Economic Review, 35, 519-530. Retrieved from www.jstor.org/stable/1809376

Hayter, R., \& Clapp, A. (2020). The remapping of forest governance: From shareholder to stakeholder. In J. Glückler, G. Herrigel, \& M. Handke (Eds.), Knowledge for governance (pp. 375-395). Knowledge and Space: Vol. 15. Cham: Springer. https://doi. org/10.1007/978-3-030-47150-7_16.

HDI [Haftpflichtverband der Deutschen Industrie]. (2018). Solvency and financial condition report 2017. Retrieved from https://www.talanx.com/ /media/Files/T/Talanx/ reports-and-presentations/2018/SFCR/2017_hdi_gruppe_sfcr_en.pdf

Hechavarria, M. (2018, May 17). Avisoran crisis económica en la industria maderera de la región [Warnings of economic crisis in the region's timber industry]. El Centro (Talca), p. 2. Retrieved from https://issuu.com/diarioelcentro/docs/diario_17-05-2018_36b8c13b9e1203/2

Hellwig, M. F. (1983). Moral hazard and monopolistically competitive insurance markets. The Geneva Papers on Risk and Insurance -Issues and Practice, 8, 44-71. https://doi.org/10.1057/ gpp. 1983.7

Ilin, T., \& Varga, L. (2015). The uncertainty of systemic risk. Risk Management, 17, 240-275. https://doi.org/10.1057/rm.2015.15 
INN [Instituto Nacional de Normalización]. (2015). Riesgo y peligro de incendios forestales en plantaciones: Terminología y clasificación [Risk and danger of forest fires in plantations: Terminology and classification]. (NCh3380).

Jarzabkowski, P., Bednarek, R., \& Spee, P. (2015). Making markets for acts of god: The practice of risk trading in the global reinsurance industry. Oxford, UK: Oxford University Press. https:// doi.org/10.1093/acprof:oso/9780199664764.001.0001

Johansen, I. L., \& Rausand, M. (2015). Ambiguity in risk assessment. Safety Science, 80, 243-251. https://doi.org/10.1016/j.ssci.2015.07.028

Julio, G. (2014). Tendencias del problema de los incendios forestales en Chile [Tendencies of the wildfire problem in Chile]. Revista Mundo Forestal, 26, 11-16. Retrieved from http://cifag.cl/ wp-content/uploads/2014/09/26.pdf

Kalthoff, H. (2005). Practices of calculation: Economic representations and risk management. Theory, Culture \& Society, 22, 69-97. https://doi.org/10.1177/0263276405051666

Kaufman, G. G., \& Scott, K. E. (2003). What is systemic risk, and do bank regulators retard or contribute to it? The Independent Review, 7, 371-391. Retrieved from https://law.stanford.edu/ publications/what-is-systemic-risk-and-do-bank-regulators-retard-or-contribute-to-it/

Kessler, O. (2015). What price culture? Calculation, commensuration, contingency, and authority in financial practices. In B. Jessop, B. Young, \& C. Scherrer (Eds.), Financial cultures and crisis dynamics (pp. 85-105). Routledge Frontiers of Political Economy: Vol. 189. Abingdon: Routledge. https://doi.org/10.4324/9781315773476

Knight, F. H. (1921). Risk, uncertainty and profit. Boston: Houghton.

Latorre, J. I., \& Rojas, N. (2016). El conflicto forestal en territorio mapuche hoy [The forest conflict in Mapuche territory today]. Ecología Política, 51, 84-87.

Little, C., Lara, A., McPhee, J., \& Urrutia, R. (2009). Revealing the impact of forest exotic plantations on water yield in large scale watersheds in South-Central Chile. Journal of Hydrology, 374, 162-170. https://doi.org/10.1016/j.jhydrol.2009.06.011

Loewe, V., Corti, D., Ruiz, J. M., \& Lobo, F. (2017). La evaluación del riesgo de incendio en plantaciones forestales para mejorar el acceso de la pyme a seguros contra incendios [Fire risk assessment in forest plantations to improve SME access to fire insurance]. Paper presented at the 7th Congreso Forestal Español, Cáceres, Extremadura. Retrieved from http://secforestales. org/publicaciones/index.php/congresos_forestales/article/view/19479/19191

Luhmann, N. (1993). Risk: A sociological theory. Berlin: Walter de Gruyter. (Original work published 1991)

Lundqvist, S. A. (2015). Why firms implement risk governance: Stepping beyond traditional risk management to enterprise risk management. Journal of Accounting and Public Policy, 34, 441-466. https://doi.org/10.1016/j.jaccpubpol.2015.05.002

MacKenzie, D. (2011). The credit crisis as a problem in the sociology of knowledge. American Journal of Sociology, 116, 1778-1841. https://doi.org/10.1086/659639

Mapuexpress (2017, February 4). Revuelo caso incendios e "intencionalidad": Zonas devastadas estaban infestadas por plagas en plantaciones forestales [Fire and "intentionality": Devastated areas were infested by plagues in forest plantations]. Mapuexpress (Chile). Retrieved from https://www.mapuexpress.org/2017/02/04/revuelo-caso-incendios-e-intencionalidad-zonasdevastadas-estaban-infestadas-por-plagas-en-plantaciones-forestales/

Martin, W. E., Martin, I. M., \& Kent, B. (2009). The role of risk perceptions in the risk mitigation process: The case of wildfire in high-risk communities. Journal of Environmental Management, 91, 489-498. https://doi.org/10.1016/j.jenvman.2009.09.007

Martínez, J., Martínez, J., \& Martín, P. (2004). El factor humano en los incendios forestales: Análisis de factores socio-económicos relacionados con la incidencia de incendios forestales en España [The human factor in forest fires: Analysis of socio-economic factors related to the incidence of forest fires in Spain]. In E. Chuvieco \& M. d. P. Martín (Eds.), Nuevas tecnologías para la estimación del riesgo de incendios forestales (pp. 101-142). Madrid: Consejo Superior de Investigaciones Científicas, Instituto de Economía y Geografía. 
McWethy, D. B., Pauchard, A., García, R. A., Holz, A., González, M. E., Veblen, T. T., Stahl, J., \& Currey, B. (2018). Landscape drivers of recent fire activity (2001-2017) in south-central Chile. PLOS ONE, 13, e0201195. https://doi.org/10.1371/journal.pone.0205287

Mermoz, M., Kitzberger, T., \& Veblen, T. T. (2005). Landscape influences on occurrence and spread of wildfires in Patagonian forests and shrublands. Ecology, 86, 2705-2715. https://doi. org/10.1890/04-1850

Millones, M. (2017, August 3). ¿Quiénes incendiaron Chile? [Who set Chile on fire?][Opinion]. El Mostrador (Santiago de Chile). Retrieved from https://www.elmostrador.cl/noticias/ opinion/2017/08/03/quienes-incendiaron-chile/

Montalba-Navarro, R., \& Carrasco, N. (2003). Modelo forestal chileno y conflicto indígena ¿ecologismo cultural mapuche? [The Chilean forestry model and indigenous conflict: Mapuche cultural ecology?]. Ecología Política, 26, 63-78. Retrieved from https://dialnet.unirioja.es/servlet/ articulo?codigo $=1255882$

Moreno del Valle, F. (2015). Orientaciones y contradicciones en la Ley de Bosque Nativo [Orientations and contradictions in the Native Forest Law]. Justicia Ambiental, 7, 163-185. Retrieved from https://cl.boell.org/sites/default/files/libro_fima_interior_y_tapas.pdf

Müller-Mahn, D., Everts, J., \& Stephan, C. (2018). Riskscapes revisited: Exploring the relationship between risk, space and practice. Erdkunde, 72, 197-213. https://doi.org/10.3112/ erdkunde.2018.02.09

North, D. (1990). Institutions, institutional change and economic performance. Cambridge, UK: Cambridge University Press.

November, V. (2008). Commentary: Spatiality of risk. Environment and Planning A, 40, 1523-1527. https://doi.org/10.1068/a4194

O’Flanagan, P. (1997). ¿Incendiarismo o ecocidio en la Iberia Atlántica? La transformación del paisaje a causa del fuego: Reflejo de los problemas socioeconómicos [Incendiarism or ecocide in Atlantic Iberia? The transformation of the landscape by fire: A reflection of the socioeconomic problems]. Polígonos, 7, 77-96. https://doi.org/10.18002/pol.v0i7.1050

O'Malley, P. (2004). Risk, uncertainty and government. London: The GlassHouse.

Perrow, C. (1986). Complex organizations: A critical essay (3rd ed.). New York: Random House. (Original work published 1972)

Renn, O. (2008). Risk governance: Coping with uncertainty in a complex world. London: Routledge. https://doi.org/10.4324/9781849772440

Renn, O. (2020). Risk governance: From knowledge to regulatory action. In J. Glückler, G. Herrigel, \& M. Handke (Eds.), Knowledge for governance (pp. 93-111). Knowledge and Space: Vol. 15. Cham: Springer. https://doi.org/10.1007/978-3-030-47150-7_5

Reyes, R., \& Nelson, H. (2014). A tale of two forests: Why forests and forest conflicts are both growing in Chile. International Forestry Review, 16, 379-388. https://doi. org/10.1505/146554814813484121

Rojas, N., \& Miranda, O. (2015). Dinámica sociopolítica del conflicto y la violencia en territorio mapuche: Particularidades históricas de un nuevo ciclo en las relaciones contenciosas [Sociopolitical dynamics of the conflict and violence in Mapuche territory]. Revista de Sociología, 30, 33-69. https://doi.org/10.5354/0719-529X.2015.46411

Rosa, E. A., Renn, O., \& McCright, A. M. (2014). The risk society revisited: Social theory and governance. Philadelphia, PA: Temple University Press.

Saavedra, O. (2017, January 29). Productores de madera: "Tenemos temores fundados ... Nos enfrentamos al terrorismo" [Timber producers: "We have well-founded fears ... We are facing terrorism"]. El Mercurio (Santiago de Chile). Retrieved from http://www.economiaynegocios. $\mathrm{cl} /$ noticias/noticias.asp?id=331220

Salvati, L., \& Ranalli, F. (2015). "Land of fires": Urban growth, economic crisis, and forest fires in Attica, Greece. Geographical Research, 53, 68-80. https://doi.org/10.1111/1745-5871.12093

Segovia, P., Basulto, O., \& Zambrano, P. (2018). Imaginarios sociales y representaciones: Su aplicación a análisis discursivos en tres ámbitos diferentes [Social imaginaries and represen- 
tations: Its application to discursive analysis in three different fields]. EMPIRIA: Revista de Metodología de Ciencias Sociales, 41, 79-102. https://doi.org/10.5944/empiria.41.2018.22605

Seguel, A. (2018). Chile: Mega incendios forestales, crímenes empresariales e impunidad [Chile: Mega forest fires, corporate crime and impunity]. World Rainforest Movement Bulletin, 238. Retrieved from https://wrm.org.uy/es/articulos-del-boletin-wrm/seccion1/ chile-mega-incendios-forestales-crimenes-empresariales-e-impunidad/

Sepúlveda, J. (2013, January 4). La historia de los autoatentados incendiarios de forestal Mininco en 1999 [The story of the self-inflicted arsonists of Mininco in 1999]. Gamba (Santiago de Chile). Retrieved from http://www.gamba.cl/2013/01/ la-historia-de-los-autoatentados-incendiarios-de-forestal-mininco-en-1999/

Simon, G. L., \& Dooling, S. (2013). Flame and fortune in California: The material and political dimensions of vulnerability. Global Environmental Change, 23, 1410-1423. https://doi. org/10.1016/j.gloenvcha.2013.08.008

Soin, K., \& Collier, P. (2013). Risk and risk management in management accounting and control. Management Accounting Research, 24, 82-87. https://doi.org/10.1016/j.mar.2013.04.003

Stiglitz, J. E. (1983). Risk, incentives and insurance: The pure theory of moral hazard. The Geneva Papers on Risk and Insurance, 8, 4-33. https://doi.org/10.1057/gpp.1983.2

Tapia, G., \& Castillo, M. (2014). Propuesta de diseño de un sistema de torres de detección de incendios forestales: Aplicación a la región metropolitana de Chile central [Proposal for the design of a forest fire detection tower system: Application to the metropolitan region of central Chile]. Bosque, 35, 399-412. https://doi.org/10.4067/S0717-92002014000300014

Úbeda, X., \& Sarricolea, P. (2016). Wildfires in Chile: A review. Global and Planetary Change, 146, 152-161. https://doi.org/10.1016/j.gloplacha.2016.10.004

van Asselt, M., \& Renn, O. (2011). Risk governance. Journal of Risk Research, 14, 431-449. https://doi.org/10.1080/13669877.2011.553730

van Dam, C. (2006). Empresas forestales y comunidades rurales en el centro-sur de Chile: Externalidades sociales de un modelo 'exitoso' [Forestry companies and rural communities in south-central Chile: social externalities of a 'successful' model]. Debate Agrario, 40-41, 225-243.

van Dijk, T. A. (2014). Discourse and knowledge. Cambridge, UK: Cambridge University Press. https://doi.org/10.1017/CBO9781107775404

van Holt, T., Binford, M. W., Portier, K. M., \& Vergara, R. (2016). A stand of trees does not a forest make: Tree plantations and forest transitions. Land Use Policy, 56, 147-157. https://doi. org/10.1016/j.landusepol.2016.04.015

Vélez, R. (2009). La defensa contra incendios forestales: Fundamentos y experiencias [Protection against forest fires: Fundamentals and experiences] (2nd ed.). Madrid: McGraw-Hill.

Vergara-Díaz, G., Sandoval-Vásquez, V. A., \& Herrera-Machuca, M. A. (2017). Spatial distribution of forest plantations in southern Chile, an area with a pulp mill. Revista Chapingo Serie Ciencias Forestales y del Ambiente, 23, 121-135. https://doi.org/10.5154/r.rchscfa.2015.09.045

Viscusi, W. K., \& Magat, W. A. (1987). Learning about risk: Consumer and worker responses to hazard information. Cambridge, MA: Harvard University Press.

Young, O. R. (2010). Institutional dynamics: Resilience, vulnerability and adaptation in environmental and resource regimes. Global Environmental Change, 20, 378-385. https://doi. org/10.1016/j.gloenvcha.2009.10.001 
Open Access This chapter is licensed under the terms of the Creative Commons Attribution 4.0 International License (http://creativecommons.org/licenses/by/4.0/), which permits use, sharing, adaptation, distribution and reproduction in any medium or format, as long as you give appropriate credit to the original author(s) and the source, provide a link to the Creative Commons license and indicate if changes were made.

The images or other third party material in this chapter are included in the chapter's Creative Commons license, unless indicated otherwise in a credit line to the material. If material is not included in the chapter's Creative Commons license and your intended use is not permitted by statutory regulation or exceeds the permitted use, you will need to obtain permission directly from the copyright holder. 